\title{
Penerapan Regresi Robust pada Pengeluaran Listrik Rumah Tangga Miskin di Perkotaan dan Perdesaan Kawasan Timur Indonesia Tahun 2020
}

\author{
(Application of Robust Regression on Electricity Expenditure of Poor Households in Urban and \\ Rural Eastern Indonesia in 2020) \\ Vina Tri Yasmi ${ }^{*}$, Lia Yuliana ${ }^{2}$ \\ ${ }^{1,2}$ Politeknik Statistika STIS \\ Jl. Otto Iskandardinata No. 64 C, Bidara Cina, Jakarta Timur \\ E-mail: 211710041@stis.ac.id
}

\begin{abstract}
ABSTRAK
Kawasan Timur Indonesia (KTI) memiliki rasio elektrifikasi lebih rendah dibanding Kawasan Barat Indonesia. Artinya, terdapat lebih banyak rumah tangga di KTI yang tidak memiliki akses listrik yang juga sejalan dengan tingginya persentase kemiskinan di KTI. Persentase kemiskinan di perdesaan juga lebih tinggi dan akses listriknya lebih sulit dibanding perkotaan. Anggaran subsidi listrik yang ditujukan pada rumah tangga miskin juga terus meningkat meskipun sudah dilakukan kebijakan subsidi tepat sasaran pada tahun 2017. Oleh karena itu, penelitian ini bertujuan untuk mengetahui karakteristik sosial ekonomi dan konsumsi listrik rumah tangga miskin di perkotaan dan perdesaan KTI tahun 2020, serta menganalisis karakteristik sosial ekonomi yang memengaruhi pengeluaran listrik rumah tangga miskin di perkotaan dan perdesaan KTI tahun 2020. Data yang digunakan adalah data SUSENAS Maret 2020. Hasil penelitian dengan regresi robust menunjukkan bahwa variabel yang signifikan positif memengaruhi pengeluaran listrik rumah tangga miskin di perkotaan dan perdesaan KTI tahun 2020 adalah pendidikan tinggi KRT, jumlah ART, luas lantai, pendapatan per kapita, kepemilikan elektronik, dan variabel yang signifikan negatif adalah kepemilikan tempat tinggal. Variabel pendidikan menengah KRT signifikan positif hanya di perdesaan, sedangkan variabel yang tidak signifikan di perkotaan dan perdesaan adalah umur KRT dan kegiatan bekerja KRT.
\end{abstract}

Kata kunci: konsumsi listrik, rumah tangga miskin, regresi robust, estimasi-MM

\begin{abstract}
The Eastern Region of Indonesia (EI) has a lower electrification ratio than the Western Region of Indonesia. This means that there are more households in EI that do not have access to electricity which is also in line with the high percentage of poverty in EI. The percentage of poverty in rural areas is also higher and access to electricity is more difficult than in urban areas. The electricity subsidy budget targeting poor households also continues to increase even though the targeted subsidy policy was implemented in 2017. Therefore, this study aims to determine the socio-economic characteristics and electricity consumption of poor households in urban and rural EI in 2020, as well as analyze socio-economic characteristics that affect the electricity expenditure of poor households in urban and rural EI in 2020. The data used is SUSENAS March 2020 data. The results with robust regression indicate that the variables that had a positive significant effect on the electricity expenditure of poor households in urban and rural areas are higher education of household head, number of household members, floor area, income per capita, electronic ownership, and the significant negative is residence ownership. The secondary education of household head are only significant in rural areas, while those that are not significant in urban and rural areas are the age of household head and working activity of household head.
\end{abstract}

Keywords: electricity consumption, poor households, robust regression, MM-Estimation

\section{PENDAHULUAN}

Perkembangan teknologi yang semakin meningkat tidak lepas dari meningkatnya konsumsi listrik sebagai sumber energi utama. Konsumsi listrik rumah tangga pada 2019 memiliki proporsi yang paling tinggi terhadap total konsumsi listrik Indonesia, yaitu sebesar 42,25 persen (Direktorat Gatrik, 2020). Hal ini juga ditunjukkan oleh rasio elektrifikasi Indonesia yang sudah mencapai 98,89 persen. Artinya, dari 100 rumah tangga di Indonesia terdapat 98 hingga 99 rumah tangga yang sudah dialiri listrik. Dalam peningkatan rasio elektrifikasi tersebut, pemerintah terus berupaya melalui program pemasangan listrik yang ditujukan pada rumah tangga miskin. Peningkatan akses listrik perlu dilakukan karena menurut Kammen \& Kirubi (2008) kemiskinan energi dapat memengaruhi masyarakat miskin dan negara miskin lebih parah dibandingkan negara maju. Penelitian oleh Zuhri (2019) juga menyatakan bahwa rumah tangga dengan akses listrik memiliki peluang lebih rendah untuk berada dalam kemiskinan. 
Data BPS tahun 2015 sampai 2019 menunjukkan bahwa persentase kemiskinan Indonesia terus mengalami penurunan. Persentase penduduk miskin tahun 2019 sebesar 9,58 persen yang mana turun 14 persen dari 2015. Berdasarkan tipe daerah, persentase kemiskinan pada 2019 di perdesaan lebih besar dibanding perkotaan yang mana di perdesaan sebesar 12,6 persen, sedangkan perkotaan sebesar 6,56 persen. Hal ini mengindikasikan bahwa masyarakat miskin umumnya terkonsentrasi di wilayah perdesaan. Faktor geografi di perdesaan yang cenderung sulit juga mengakibatkan infrastruktur listrik membutuhkan biaya yang besar sehingga akses listrik di perdesaan juga sulit (Zuhri, Anggraeni, \& Irawan, 2018). Hal ini akan mengakibatkan masyarakat miskin di perdesaan terbiasa tidak menggunakan listrik atau mengonsumsi listrik dengan jumlah yang lebih sedikit dibanding perkotaan.

Demi mengatasi hal tersebut, pemerintah telah melakukan penanganan berupa berbagai program kelistrikan, salah satunya adalah subsidi listrik pada rumah tangga miskin. Tren subsidi listrik dari tahun 2015 hingga 2019 ditunjukkan oleh gambar 1. Pada tahun 2017, pemerintah melakukan kebijakan subsidi tepat sasaran dengan memotong anggaran subsidi listrik untuk rumah tangga mampu dengan daya 900VA (Kementrian ESDM, 2017). Namun, dari 2018 hingga 2020, terus terjadi peningkatan anggaran subsidi listrik untuk rumah tangga miskin. Penurunan persentase penduduk miskin yang diiringi dengan peningkatan subsidi ini mengindikasikan adanya peningkatan konsumsi listrik oleh rumah tangga miskin sehingga pemerintah perlu memperhatikan kembali pola konsumsi listrik rumah tangga miskin agar subsidi listrik dapat lebih difokuskan lagi pada masyarakat yang lebih membutuhkan.

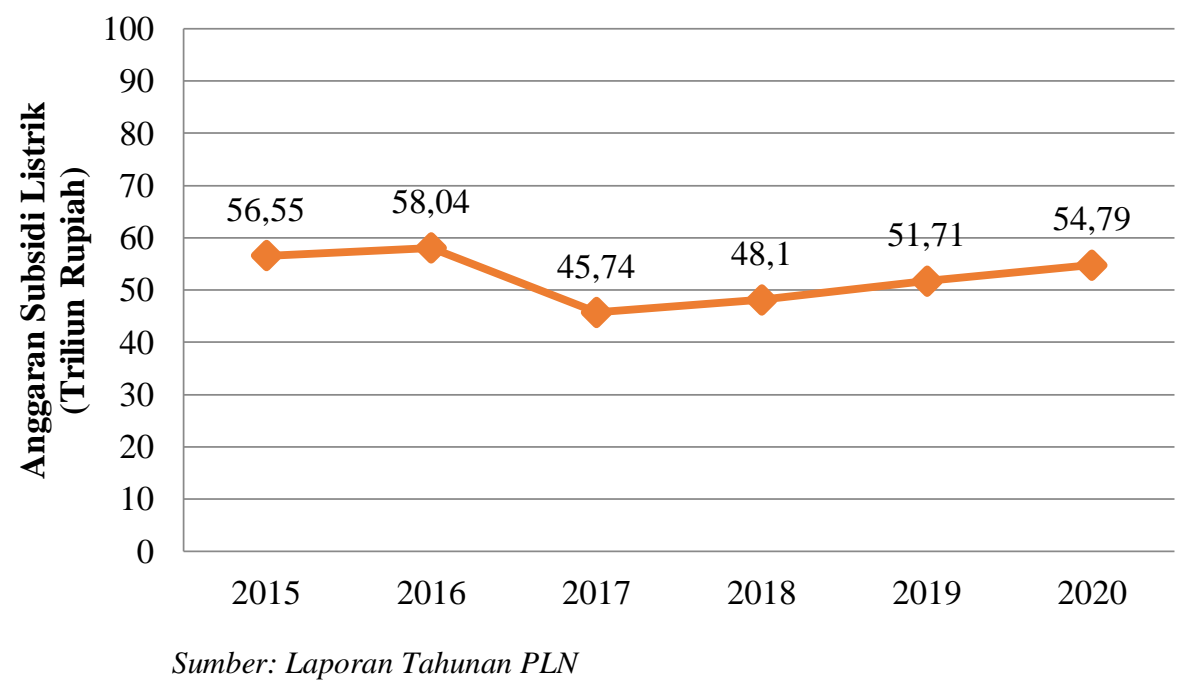

Gambar 1. Subsidi listrik Indonesia periode 2015-2020

Jika diperhatikan dari sisi kawasan di Indonesia, Kawasan Timur Indonesia memiliki rasio elektrifikasi yang lebih kecil dari rasio elektrifikasi Indonesia yaitu 98,5 persen pada 2019, yang mana juga lebih kecil bila dibandingkan dengan Kawasan Barat Indonesia yang sebesar 99,48 persen. Rasio elektrifikasi yang rendah tersebut diakibatkan oleh masih banyaknya provinsi di Kawasan Timur Indonesia yang memiliki rasio elektrifikasi di bawah rasio Indonesia. Selain itu, persentase penduduk miskin di Kawasan Timur Indonesia juga tinggi, yaitu pada 2019 sebesar 11,91 persen. Hal ini karena provinsi yang memiliki persentase penduduk miskin tertinggi mayoritas berada di Kawasan Timur Indonesia, yaitu yang tertinggi adalah Provinsi Papua sebesar 26,55 persen. Oleh karena itu, pemerintah harus memberikan perhatian yang lebih besar pada Kawasan Timur Indonesia dalam penyaluran subsidi listrik dan mengkaji lebih dalam pola konsumsi listrik rumah tangga miskin di kawasan tersebut.

Konsumsi listrik rumah tangga tidak terlepas dari keadaan rumah tangga tersebut yang dapat dilihat melalui karakteristik sosial dan ekonominya. Oleh karena itu, peneliti tertarik untuk menganalisis pengeluaran listrik rumah tangga miskin berdasarkan karakteristik sosial ekonomi di perkotaan dan perdesaan di Kawasan Timur Indonesia tahun 2020. Adapun tujuan penelitian ini adalah (1) melihat gambaran umum karakteristik sosial ekonomi dan konsumsi listrik rumah tangga miskin di perkotaan dan perdesaan KTI tahun 2020, dan (2) menganalisis karakteristik sosial ekonomi yang memengaruhi konsumsi listrik rumah tangga miskin di perkotaan dan perdesaan Kawasan Timur Indonesia tahun 2020.

Penelitian yang membahas konsumsi listrik rumah tangga di antaranya adalah penelitian Kim (2019) yang menunjukkan variabel yang signifikan memengaruhi konsumsi listrik rumah tangga adalah umur KRT, jumlah ART, daerah tempat tinggal, dan jumlah alat elektronik. Selanjutnya, Nazer \& Hendra (2016) menyebutkan variabel yang signifikan memengaruhi konsumsi listrik rumah tangga di perkotaan Indonesia adalah pendapatan rumah tangga, luas lantai, kepemilikan barang elektronik, kepemilikan tempat tinggal, dan usia 
KRT. Kemudian, Wijaya \& Tezuka (2013) menyebutkan variabel yang signfikan memengaruhi konsumsi listrik rumah tangga di Bandung dan Yogyakarta adalah pendapatan rumah tangga, jumlah ART, tingkat pendidikan, waktu beraktivitas, luas lantai, dan penggunaan alat elektronik.

\section{METODE}

\section{Landasan Teori}

Badan Pusat Statistik menggunakan konsep kemampuan memenuhi kebutuhan dasar (basic needs method) yang menganggap kemiskinan sebagai ketidakmampuan untuk memenuhi kebutuhan dasar berupa makanan dan non-makanan yang diukur dari sisi pengeluaran. Dalam menentukan standar kebutuhan dasar, BPS menggunakan suatu batasan yang disebut garis kemiskinan. Garis kemiskinan adalah tingkat minimum pendapatan yang dianggap perlu dipenuhi untuk memperoleh standar hidup yang mencukupi di suatu negara.

Permintaan energi listrik rumah tangga dapat didekati dengan beberapa pendekataan seperti daya meteran di rumah tangga, konsumsi energi listrik dalam $\mathrm{kWh}$ ataupun dalam rupiah selama sebulan terakhir. Penelitian ini menggunakan pendekatan pengeluaran listrik dalam rupiah. Pengeluaran listrik dalam rupiah merupakan jumlah tagihan listrik rumah tangga yang dibayarkan kepada PLN selama satu bulan dengan satuan rupiah. Anderson (1973) dalam Alter \& Syed (2011) memandang bahwa selain pendapatan dan harga komoditas listrik, perlu diperhitungkan aspek geografi, demografi, dan kebiasaan sosial rumah tangga dalam menganalisis permintaan listrik rumah tangga. Sedangkan Wilder dan Willenborg (1975) dalam Alter \& Syed (2011) menguraikan bahwa permintaan listrik rumah tangga merupakan turunan permintaan dari permintaan alat elektronik (peralatan, jasa elektronik, dan barang elektronik lain). Kemudian, disimpulkan oleh Alter \& Syed (2011) bahwa pengaruh paling krusial yang menentukan permintaan listrik selain faktor ekonomi (pendapatan, harga, dan barang elektronik) adalah variabel sosial ekonomi, demografi, geografi dan meteorology.

Menurut Nazer \& Hendra (2016), terdapat kecenderungan semakin bertambahnya usia kepala rumah tangga menyebabkan waktu di rumah semakin panjang sehingga akan menaikkan kebutuhan energy. Kemudian, menurut Huang (2015) seseorang yang berpendidikan tinggi dapat memiliki pendapatan yang lebih tinggi sehingga berkemungkinan mengejar kualitas hidup yang lebih baik dengan mengonsumsi listrik lebih banyak dibanding orang yang berpendidikan rendah. Selain itu, penelitian oleh Romadhoni \& Akhmad (2020) menyatakan bahwa setiap tambahan anggota rumah tangga akan menaikkan penggunaan listrik rumah tangga. Menurut Purnomo (2020), semakin luas suatu bangunan rumah maka penerangan yang dibutuhkan akan semakin banyak. Semakin banyak penerangan akan meningkatkan pemakaian listrik dan pengeluaran listrik akan semakin besar.

Sukirno (2013) menyebutkan bahwa pendapatan rumah tangga merupakan faktor penting yang menentukan konsumsi suatu rumah tangga. Hal tersebut sejalan dengan hasil penelitian oleh Petersen (1982) yang menyatakan kenaikan konsumsi listrik dapat terjadi karena rumah tangga dengan pendapatan tinggi akan cenderung memiliki lebih banyak barang yang menggunakan listrik. Teori konumsi Keynes menyebutkan bahwa pengeluaran secara langsung dipengaruhi oleh tingkat pendapatannya. Sehingga kepala rumah tangga yang bekerja akan memiliki pendapatan yang cukup untuk membayar konsumsi listrik. Hal tersebut sesuai dengan dengan penelitian oleh Hartono, Hastuti, Balya, \& Pramono (2020) yang menunjukkan kepala rumah tangga yang berstatus bekerja akan berkaitan positif dengan pengeluaran energi. Teori konsumsi hipotesis pendapatan permanen oleh Friedman, Albert Ando dan Franco Modigliani menyatakan bahwa hasil bersih dari suatu kekayaan merupakan faktor penting dalam menentukan konsumsi karena memiliki hubungan positif dan proporsional dengan pendapatannya. Kepemilikan bangunan tempat tinggal merupakan faktor yang dapat menunjukkan kekayaan rumah tangga. Sejalan dengan penelitian oleh Nazer \& Hendra (2016) yang menyebutkan bahwa rumah tangga yang menempati rumah milik sendiri akan mengonsumsi energi lebih banyak dari rumah tangga yang menempati rumah kontrak, bebas sewa, dinas, milik orang tua/saudara, lainnya. Kemudian, penelitian oleh Wijaya \& Tezuka (2013) menyebutkan bahwa peningkatan kepemilikan barang elektronik akan menyebabkan tingkat pertumbuhan konsumsi listrik rumah tangga meningkat.

\section{Metode Analisis}

Metode analisis yang digunakan adalah analisis deskriptif dan analisis inferensia. Analisis deskriptif menunjukkan gambaran umum karakteristik sosial ekonomi dan konsumsi listrik rumah tangga miskin Kawasan Timur Indonesia dengan merinci wilayah perdesaan dan perkotaan pada tahun 2020 dengan menggunakan tabel dan grafik. Sementara itu, analisis inferensia menggunakan metode regresi robust estimasiMM untuk menganalisis karakteristik sosial ekonomi yang memengaruhi konsumsi listrik rumah tangga 
miskin di perdesaan dan perkotaan Kawasan Timur Indonesia tahun 2020. Sehingga, terdapat dua model dalam penelitian ini, yaitu:

a. Model pengeluaran listrik rumah tangga miskin di perkotaan

$P L S_{\text {KOT } A_{i}}=\beta_{0}+\beta_{1}\left(\right.$ Umur_KRT $_{i}+\beta_{2}\left(\text { DPendidikan } 1_{-} K R T\right)_{i}+\beta_{3}(\text { DPendidikan2_KRT })_{i}+$

$\beta_{4}(\text { Jumlah_ART })_{i}+\beta_{5}(\text { Luas_Lantai })_{i}+\beta_{6}(\text { Pendapatan_perKapita })_{i}+\beta_{7}(\text { DKegiatan_Kerja })_{i}+$

$\beta_{8}(\text { DKepemilikan_TT })_{i}+\beta_{9}(\text { Kepemilikan_Elekt })_{i}+\varepsilon_{i}$

b. Model pengeluaran listrik rumah tangga miskin di perdesaan

$P L S_{D E S A_{i}}=\beta_{0}+\beta_{1}(\text { Umur_KRT })_{i}+\beta_{2}(\text { DPendidikan1_KRT })_{i}+\beta_{3}(\text { DPendidikan2_KRT })_{i}+$

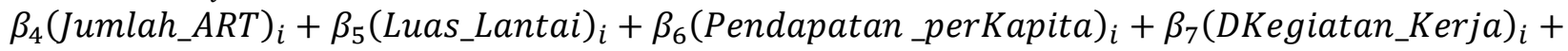

$\beta_{8}(\text { DKepemilikan_TT })_{i}+\beta_{9}(\text { Kepemilikan_Elekt })_{i}+\varepsilon_{i}$

Keterangan:

$P L S_{i}$

$\beta_{0}$

Umur_KRT

Luas_Lantai

$=$ pengeluaran listrik rumah tangga (Rupiah)

$=$ intercept

$=$ umur kepala rumah tangga (tahun)

$=$ luas lantai bangunan tempat tinggal $\left(\mathrm{m}^{2}\right)$

Jumlah_ART = jumlah anggota rumah tangga (orang)

Pendapatan_perKapita $=$ pendapatan per kapita rumah tangga (Rupiah)

DPendidikan1_KRT = dummy pendidikan tinggi kepala rumah tangga $(1:>$ SMA, $0:<=S D)$

DPendidikan2_KRT = dummy pendidikan menengah kepala rumah tangga (1: SMP-SMA, $0:<=\mathrm{SD})$

DKegiatan_Kerja = dummy kegiatan bekerja kepala rumah tangga (1: bekerja, 0 : tidak bekerja)

DKepemilikan_TT = dummy status kepemilikan tempat tinggal (1: milik sendiri, 0 : bukan milik sendiri)

Kepemilikan_Elekt = jumlah kepemilikan alat elektronik

$\varepsilon_{i}$

= error term

Regresi robust merupakan metode regresi yang digunakan untuk menganalisis data yang terkontaminasi pencilan dengan membatasi pengaruh dari pencilan tersebut terhadap nilai estimasinya (Andersen, 2008). Sifat kekar (robustness) tersebut tercapai dengan memberikan penimbang yang berbeda pada data dalam perhitungan estimasi, sehingga data pencilan memiliki pengaruh yang lebih kecil terhadap estimator regresi (Stuart, 2011). Dalam pembentukan model regresi dan melakukan uji asumsi, sering ditemui bahwa asumsi regresi dilanggar, transformasi yang dilakukan tidak menghilangkan atau melemahkan pengaruh dari pencilan yang akhirnya prediksi menjadi bias (Susanti, Pratiwi, \& Sulistijow, 2013). Sehingga, regresi robust adalah metode terbaik untuk memberikan hasil yang resisten terhadap pencilan.

Metode yang paling sering digunakan dalam regresi robust adalah estimasi Huber M, high breakdown point, dan kombinasi kedua metode tersebut. Breakdown point menunjukkan derajat kekekaran suatu estimasi terhadap keberadaan outlier (Yohai, 1987). Wilcox (2012) menyebutkan salah satu estimasi regresi robust adalah estimasi-MM oleh Yohai (1987) yang memiliki nilai breakdown tertinggi yaitu 0,5 dan memiliki efisiensi tinggi yaitu 95 persen bila dibandingkan dengan metode kuadrat terkecil yang berdistribusi normal. Metode estimasi MM cocok digunakan untuk data yang memiliki pencilan pada variabel bebas dan variabel tak bebas (Nurdin, Raupong, \& Islamiyati, 2014). Estimasi-MM didefinisikan sebagai berikut (Susanti, Pratiwi, \& Sulistijow, 2013)

$$
\begin{gathered}
\hat{\beta}_{M M}=\sum_{i=1}^{n} x_{i j} \rho_{1}{ }^{\prime}\left(\frac{y_{i}-\sum_{j=0}^{p-1} x_{i j} \beta_{j}}{\widehat{\sigma}_{S}}\right)=\sum_{i=1}^{n} x_{i j} \rho_{1}{ }^{\prime}\left(\frac{e_{i}}{\widehat{\sigma}_{S}}\right)=\sum_{i=1}^{n} x_{i j} \rho_{1}{ }^{\prime}\left(u_{i}\right)=0 \\
j=0,1,2, \ldots, p-1
\end{gathered}
$$

Di mana p adalah parameter, $\rho_{1}{ }^{\prime}$ adalah turunan dari $\rho$ yang merupakan fungsi objektif untuk menentukan fungsi pembobot, $e_{i}$ adalah residual yang diperoleh dengan estimasi-S, $x_{i j}$ adalah observasi ke-i pada variabel bebas ke-j dengan $x_{i 0}=1$, dan $\hat{\sigma}_{s}$ diperoleh dari rumus berikut:

$$
\hat{\sigma}_{S}=\sqrt{\frac{1}{n(0,199)} \sum_{i=1}^{n} w_{i} e_{i}^{2}}
$$

Metode MM dilakukan menggunakan IRLS (Iteratively Reweighted Least Square) untuk mencari estimasi parameter regresi. Prosedur penghitungan nilai estimasi parameter model regresi robust dengan estimasi-MM ialah sebagai berikut (Susanti, Pratiwi, \& Sulistijow, 2013):

1. Melakukan estimasi koefisien regresi pada data menggunakan Metode Kuadrat Terkecil

2. Menguji asumsi klasik dari model regresi

3. Mendeteksi adanya pencilan dalam data

4. Mengestimasi koefisien regresi robust menggunakan estimasi-MM 
a. Megestimasi parameter model regresi dengan estimasi-S

1) Menghitung estimator awal koefisien $\hat{\beta}_{0}$ dengan MKT

2) Menghitung residual $e_{i}$

3) Menghitung nilai $\hat{\sigma}_{i}$ dengan persamaan

$$
\hat{\sigma}_{i}= \begin{cases}\frac{\text { median } \mid e_{i}-\text { median }\left(e_{i}\right) \mid}{0,6745} & , \text { iteras } i=1 \\ \sqrt{\frac{1}{n(0,199)} \sum_{i=1}^{n} w_{i} e_{i}^{2}} & , \text { iteras } i>1\end{cases}
$$

4) Menghitung $u_{i}=\frac{e_{i}}{\widehat{\sigma}_{i}}$

5) Menghitung nilai pembobot $w_{i}$

$$
w_{i}= \begin{cases}{\left[1-\left(\frac{u_{i}}{c}\right)^{2}\right]^{2}} & \left|u_{i}\right| \leq 1,547 \\ 0 & \left|u_{i}\right|>1,547\end{cases}
$$

6) Mengestimasi parameter model regresi dengan metode weighted least square (WLS) dengan pembobot $w_{i}$ sehingga diperoleh sisaan yang baru

7) Menjadikan sisaan langkah (6) sebagai sisaan awal langkah (2) sehingga diperoleh nilai $u_{i}$ dan $w_{i}$ yang baru

8) Iterasi diulang sampai nilai $\hat{\beta}_{j}$ konvergen

b. Menghitung nilai $e_{i}$ dari estimasi-S

c. Menghitung nilai $\hat{\sigma}_{i}=\hat{\sigma}_{S}$

d. Menghitung $u_{i}=\frac{e_{i}}{\hat{\sigma}_{i}}$

e. Menghitung pembobot

$$
w_{i}=\left\{\begin{array}{cc}
{\left[1-\left(\frac{u_{i}}{4,685}\right)^{2}\right]^{2}} & \left|u_{i}\right| \leq 4,685 \\
0 & \left|u_{i}\right|>4,685
\end{array}\right.
$$

f. Menghitung parameter $\hat{\beta}_{M M}$ dengan metode WLS dengan pembobot $w_{i}^{0}$

g. Mengulangi langkah c sampai f sampai diperoleh nilai $\hat{\beta}_{M M}$ yang konvergen

h. Melakukan uji hipotesis (pengujian keberartian model)

\section{Data dan Sumber Data}

Penelitian ini menggunakan data sekunder berupa data cross section dari SUSENAS Kor Maret 2020 dan SUSENAS Modul Konsumsi/Pengeluaran Maret 2020. Unit analisis dalam penelitian ini adalah 9009 rumah tangga miskin yang memiliki sumber penerangan utama PLN di Kawasan Timur Indonesia, yang terbagi atas 1781 rumah tangga miskin di Perkotaan dan 7228 rumah tangga miskin di Perdesaan. Variabel terikat dalam penelitian ini adalah pengeluaran listrik rumah tangga, sedangkan variabel bebasnya antara lain umur KRT, tingkat pendidikan KRT, jumlah ART, luas lantai, pendapatan per kapita, kegiatan bekerja, status kepemilikan tempat tinggal, dan kepemilikan elektronik.

\section{HASIL DAN PEMBAHASAN}

\section{Gambaran Umum Karakteristik Sosial Ekonomi dan Konsumsi Listrik Rumah Tangga Miskin di Perdesaan dan Perkotaan Kawasan Timur Indonesia Tahun 2020}

Berdasarkan hasil pengolahan data Susenas Maret 2020, 91 persen rumah tangga di KTI bukan rumah tangga miskin, sedangkan 9 persen sisanya adalah rumah tangga miskin. Persentase rumah tangga miskin yang menggunakan lisrik PLN di perdesaan dan perkotaan Kawasan Timur Indonesia ditunjukkan oleh Gambar 2. Di perdesaan, terdapat 70 persen rumah tangga miskin yang memanfaatkan listrik PLN dan sisanya 30 persen berada di perkotaan. 


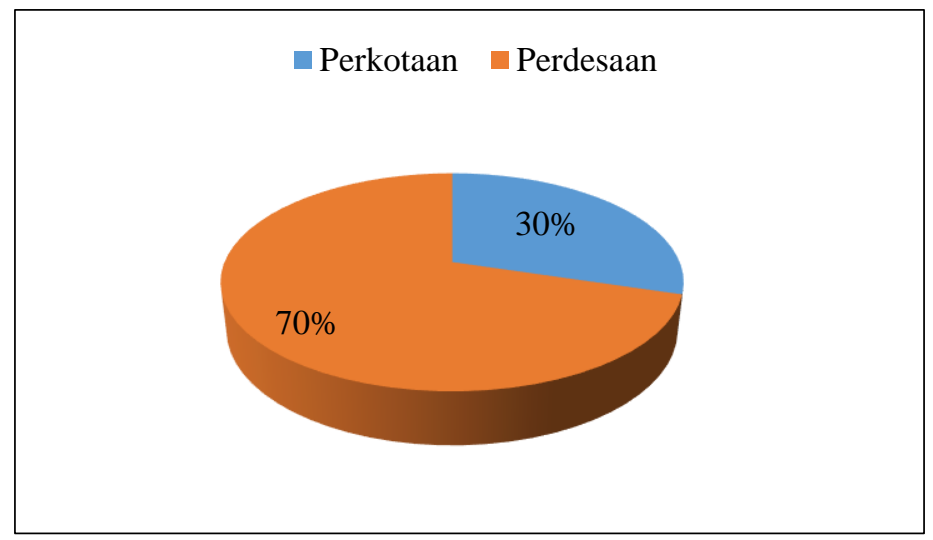

Sumber: Susenas Maret 2020, diolah

Gambar 2. Persentase rumah tangga miskin dengan sumber utama penerangan PLN

Dari seluruh rumah tangga miskin yang memanfaatkan listrik dari PLN tersebut, rata-rata pengeluaran listrik rumah tangga miskin di perkotaan ialah Rp45.727,61, sedangkan pengeluaran listrik rumah tangga miskin di perdesaan ialah Rp36.465,06. Selanjutnya, gambaran mengenai rumah tangga miskin yang menggunakan listrik PLN di KTI pada tahun 2020 berdasarkan pendidikan KRT, kegiatan bekerja KRT, status kepemilikan tempat tinggal, dan kepemilikan elektronik di perkotaan ditunjukkan oleh gambar 3 dan untuk perdesaan ditunjukkan oleh gambar 4

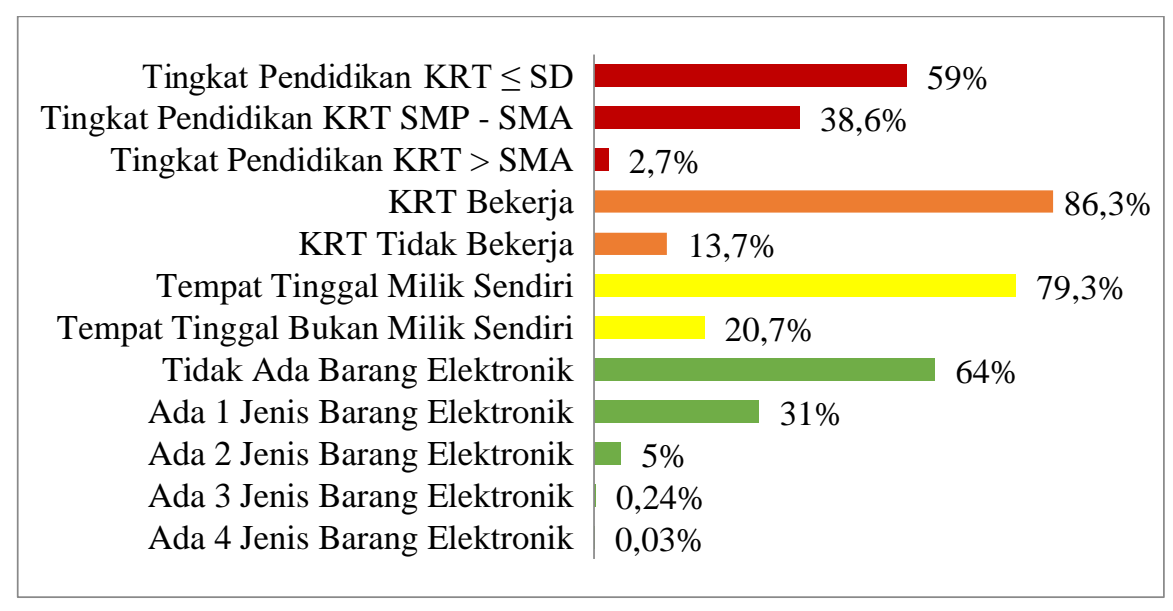

Sumber: Susenas Maret 2020, diolah

Gambar 3. Persentase rumah tangga miskin menurut beberapa karakteristik sosial ekonomi di perkotaan KTI tahun 2020

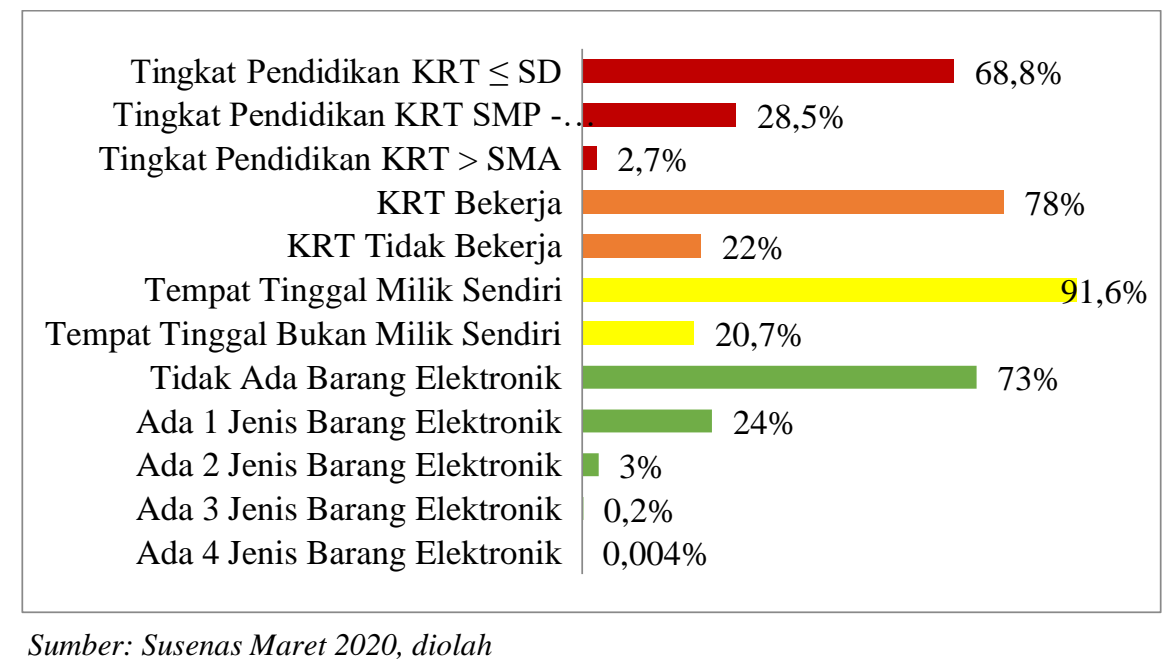

Gambar 4. Persentase rumah tangga miskin menurut beberapa karakteristik sosial ekonomi di perdesaan KTI tahun 2020 
Kemudian, gambaran mengenai rumah tangga miskin yang menggunakan listrik PLN di KTI pada tahun 2020 berdasarkan variabel umur KRT, jumlah ART, luas lantai, dan pendapatan per kapita rumah tangga miskin di perkotaan dan perdesaan oleh tabel 1 .

Tabel 1. Rata-rata umur KRT, jumlah ART, luas lantai, dan pendapatan per kapita rumah tangga miskin di perkotaan dan perdesaan KTI tahun 2020

\begin{tabular}{ccc}
\hline Variabel & & Rata-rata \\
\cline { 2 - 3 } & Perkotaan & Perdesaan \\
\hline (1) & $(2)$ & $(3)$ \\
\hline Umur KRT (tahun) & 47,73 & 48,40 \\
Jumlah ART (orang) & 5,22 & 5,13 \\
Luas Lantai (m ${ }^{2}$ ) & 51,18 & 55,68 \\
Pendapatan per Kapita (rupiah) & $386.546,11$ & $346.616,09$ \\
\hline
\end{tabular}

Sumber: Susenas Maret 2020, diolah

Berdasarkan gambar 2 dan 3 serta tabel 1, dapat diketahui bahwa karakteristik rumah tangga miskin yang memanfaatkan listrik dari PLN di perkotaan dan perdesaan adalah sebagian besar KRT berpendidikan maksimal SD, berstatus bekerja, menempati tempat tinggal milik sendiri, dan tidak memiliki barang elektronik. Rumah tangga miskin di perkotaan dikepalai oleh KRT yang lebih muda, luas tempat tinggal lebih kecil, dan pendapatan per kapita yang lebih besar bila dibandingkan dengan rumah tangga miskin di perdesaan. Sedangkan, jumlah ART antara perkotaan dan perdesaan sama yaitu 5 hingga 6 orang,

\section{Pengaruh Karakteristik Sosial Ekonomi terhadap Konsumsi Listrik Rumah Tangga Miskin di Perkotaan dan Perdesaan Kawasan Timur Indonesia Tahun 2020}

Estimasi parameter dengan menggunakan metode analisis regresi linier bergandang dengan estimasi MKT memberikan hasil pengujian simultan dengan nilai F-hitung untuk persamaan perkotaan ialah 101,80 dengan pvalue 0,00 dan persamaan perdesaan memiliki nilai F-hitung 173,25 dengan pvalue 0,00. Artinya, dengan tingkat kepercayaan 95 peren, minimal terdapat 1 variabel bebas yang signifikan memengaruhi pengeluaran listrik rumah tangga miskin baik di perkotaan maupun di perdesaan KTI tahun 2020. Hasil pengujian parsial menunjukkan variabel yang signifikan memengaruhi pengeluaran listrik rumah tangga miskin di perkotaan adalah jumlah ART, pendapatan per kapita, status kepemilikan tempat tinggal, dan status kepemilikan elektronik. Kemudian, nilai adjusted $R^{2}$ menjelaskan sebesar 34 persen keragaman pengeluaran listrik rumah tangga miskin di perkotaan dapat dijelaskan oleh variabel bebas di dalam model. Sedangkan, hasil pengujian parsial di perdesaan menunjukkan variabel yang signifikan memengaruhi pengeluaran listrik rumah tangga miskin ialah luas lantai, jumlah ART, umur KRT, pendpaatan per kapita, status kepemilikan rumah, dan kepemilikan elektronik. Nilai adjusted $R^{2}$ menjelaskan sebesar 17 persen keragaman pengeluaran listrik rumah tangga miskin di perdesaan dapat dijelaskan oleh variabel bebas di dalam model.

Kemudian, dilakukan pengujian asumsi klasik. Pengujian asumsi non multikolinearitas terpenuhi karena tidak ada nilai VIF setiap variabel dari masing-masing model yang lebih besar dari 10. Sedangkan asumsi normalitas tidak terpenuhi karena pvalue masing-masing model kecil dari 0,05 yang menyebabkan tolak $\mathrm{H} 0$, artinya asumsi error berdistribusi normal tidak terpenuhi. Kemudian, asumsi homoskedastisitas juga tidak terpenuhi karena masih ada variabel di masing-masing model yang memiliki pvalue kecil dari 0,05 yang menunjukkan adanya variabel bebas yang memengaruhi absolut residual masing-masing model. Akibat tidak terpenuhinya asumsi tersebut, maka dilakukan pendeteksian keberadaan pencilan.

Pendeteksian keberadaan pencilan perlu dilakukan karena estimasi MKT sensitif terhadap keberadaan pencilan. Berdasarkan pendeteksian pencilan pada variabel terikat, terdapat sebanyak 6,9 persen amatan di perkotaan dan 6,1 persen amatan di perdesaan adalah amatan pencilan. Kemudian, pendeteksian pencilan pada variabel bebas menunjukkan sebanyak 5,1 persen amatan di perkotaan dan 7 persen amatan di perdesaan adalah amatan pencilan. Selanjutnya, dilakukan pendeteksian amatan pencilan yang berpengaruh pada variabel terikat dan variabel bebas. Di perkotaan, dari seluruh amatan pencilan pada variabel terikat terdapat 67,5 persen adalah pencilan berpengaruh. Kemudian dari seluruh amatan pencilan pada variabel bebas di perkotaan, sebanyak 27,8 persen adalah pencilan berpengaruh. Sementara itu di perdesaan, dari seluruh pencilan pada variabel terikat terdapat 62,2 persen adalah pencilan berpengaruh. Kemudian dari seluruh amatan pencilan pada variabel bebas di perdesaan, sebanyak 28,8 persen adalah pencilan berpengaruh.

Draper \& Smith (1992) menyebutkan bahwa penghapusan data pencilan dari data sampel bukan langkah yang bijaksanan karena terkadang pencilan dapat memberikan informasi yang tidak dapat diberikan oleh observasi lain. Sehingga, digunakan metode analisis regresi robust estimasi MM yang menghasilkan model 
yang kekar terhadap keberadaan pencilan. Hasil estimasi parameter dengan regresi robust estimasi MM ditunjukkan oleh tabel 2.

Tabel 2. Hasil estimasi parameter dengan regresi robust estimasi MM

\begin{tabular}{lllll}
\hline Variabel bebas & Perkotaan & \multicolumn{3}{l}{ Perdesaan } \\
\cline { 2 - 5 } & Koefisien & t-value & Koefisien & t-value \\
\hline (1) & $(2)$ & $(3)$ & $(5)$ & $(6)$ \\
\hline Intercept & $-26982,82$ & $-7,66^{*}$ & $-889,53$ & $-0,52$ \\
Umur KRT & 65,47 & 1,54 & 17,68 & 0,98 \\
Pendidikan Tinggi KRT & 5375,50 & $1,76^{*}$ & 3130,86 & $2,44^{*}$ \\
Pendidikan Menengah KRT & $-216,76$ & $-0,19$ & 1114,24 & $2,27^{*}$ \\
Jumlah ART & 3441,45 & $13,21^{*}$ & 1700,00 & $15,57^{*}$ \\
Luas Lantai & 31,78 & $1,99^{*}$ & 85,17 & $11,69^{*}$ \\
Pendapatan per Kapita & 0,11 & $20,39^{*}$ & 0,044 & $18,13^{*}$ \\
Status Bekerja & $-368,22$ & $-0,27$ & $-47,76$ & $-0,07$ \\
DKepemilikan Tempat Tinggal & $-6406,64$ & $-4,99^{*}$ & $-1481,69$ & $-1,84^{*}$ \\
Kepemilikan Elekt & 12292,01 & $13,67^{*}$ & 7078,77 & $17,09^{*}$ \\
\hline & \multicolumn{4}{c}{ t-tabel $=1,64$} \\
& Fhitung $=257,21$ & Fhitung $=396,33$ \\
& F-tabel $=1,88$ & F-tabel $=1,88$ & Adjusted $\mathrm{R}^{2}=0,33$ \\
\cline { 2 - 5 } & Adjusted $\mathrm{R}^{2}=0,56$ &
\end{tabular}

Sumber: Susenas Maret 2020, diolah

Keterangan: *signifikan pada taraf signifikansi 5 persen

Berdasarkan hasil pengujian simultan pada tabel 2, diperoleh bahwa nilai F-hitung wilayah perkotaan adalah 257,21 dengan F-tabel sebesar 1,88 dan nilai F-hitung di perdesaan adalah 396,33 dengan F-tabel sebesar 1,88 yang berarti $\mathrm{H}_{0}$ ditolak. Sehingga, dapat disimpulkan bahwa dengan tingkat kepercayaan 95 peren, minimal terdapat satu variabel bebas yang signifikan memengaruhi pengeluaran listrik rumah tangga miskin baik di perkotaan maupun di perdesaan KTI tahun 2020.

Hasil uji parsial pada tabel 2 menunjukkan variabel yang memengaruhi pengeluaran listrik rumah tangga miskin di perkotaan KTI tahun 2020 adalah pendidikan tinggi KRT, jumlah ART, luas lantai, pendapatan per kapita, kepemilikan tempat tinggal, dan kepemilikan barang elektronik. Sedangkan variabel yang memengaruhi pengeluaran listrik rumah tangga miskin di perdesaan KTI tahun 2020 adalah pendidikan tinggi KRT, pendidikan menengah KRT, jumlah ART, luas lantai, pendapatan per kapita, kepemilikan tempat tinggal, dan kepemilikan barang elektronik.

Kemudian, hasil pengujian kebaikan dan kesesuaian model dengan adjusted $\mathrm{R}^{2}$ pada tabel 2 menjelaskan bahwa nilai adjusted R2 di perkotaan sebesar 0,56. Artinya, model robust yang terbentuk dapat menjelaskan 56 persen keragaman pegeluaran listrik rumah tangga miskin di perkotaan, sedangkan sisanya dijelaskan oleh variabel lain di luar model. Kemudian, nilai adjusted $\mathrm{R}^{2}$ di perdesaan sebesar 0,33 . Artinya, model robust yang terbentuk dapat menjelaskan 33 persen keragaman pegeluaran listrik rumah tangga miskin di perdesaan, sedangkan sisanya dijelaskan oleh variabel lain di luar model.

Di perkotaan, kepala rumah tangga yang berpendidikan tinggi memiliki pengeluaran listrik Rp5.375,50 lebih besar dibanding yang berpendidikan dasar. Sedangkan pendidikan menengah KRT di perkotaan tidak signifikan. Hal ini mengindikasikan bahwa konsumsi listrik rumah tangga di perkotaan antara KRT berpendidikan dasar dan menengah tidak berbeda jauh karena tingkat konsumsi di perkotaan yang sudah cenderung tinggi. Di perdesaan, kepala rumah tangga yang berpendidikan tinggi memiliki pengeluaran listrik Rp3.130,86 lebih besar dibanding yang berpendidikan dasar. Sedangkan kepala rumah tangga yang berpendidikan menengah memiliki pengeluaran listrik Rp1.114,24 lebih besar dibanding yang berpendidikan dasar. Hal ini berarti semakin tinggi pendidikan KRT maka semakin meningkat konsumsi listrik rumah tangganya. Hasil ini sesuai dengan penelitian oleh Huang (2015) yang menyebutkan bahwa orang yang berpendidikan lebih tinggi kemungkinan mengejar kualitas hidup yang lebih baik sehingga mengonsumsi listrik lebih besar.

Penambahan jumlah ART meningkatkan konsumsi listrik rumah tangga miskin. Di perkotaan, penambahan 1 orang ART menambah pengeluaran listrik sebesar Rp3.441,45. Sementara itu di perdesaan, penambahan 1 orang ART akan menambah pengeluaran listrik sebesar Rp1.700. Hal ini sejalan dengan hasil 
penelitian oleh Bedir, Hasselaar, \& Itard (2013) dan Kim (2020) yang menunjukan bahwa semakin banyak anggota rumah tangga maka semakin tinggi intensitas penggunaan listriknya.

Semakin luas tempat tinggal rumah tangga miskin akan meningkatkan konsumsi listrik rumah tangga tersebut. Di perkotaan, setiap penambahan $10 \mathrm{~m}^{2}$ luas lantai akan menambah pengeluaran listrik rumah tangga miskin sebesar Rp317,80. Sementara itu di perdesaan, penambahan $10 \mathrm{~m}^{2}$ luas lantai akan menambah pengeluaran listrik rumah tangga miskin sebesar Rp851,70. Semakin luas tempat tinggal maka akan semakin banyak barang elektronik yang dibutuhkan rumah tangga, seperti untuk penerangan, sehingga konsumsi listrik meningkat (Yohanis, Mondol, Wright, \& Norton, 2008)

Pendapatan per kapita rumah tangga dapat menunjukkan kesejahteraan rumah tangga. Semakin tinggi pendapatan rumah tangga maka semakin baik ekonomi rumah tangga tersebut. Kenaikan Rp100.000 pendapatan per kapita rumah tangga miskin di perkotaan akan menambah pengeluaran listrik sebesar Rp11.000. Sementara itu di perdesaan, kenaikan Rp100.000 pendapatan per kapita rumah tangga miskin di perdesaan akan menambah pengeluaran listrik sebesar Rp4.400. Hasil ini sejalan dengan teori Engel yang menyebutkan bahwa peningkatan pendapatan akan meningkatkan pengeluaran.

Rumah tangga miskin di perkotaan yang menempati rumah milik sendiri memiliki pengeluaran listrik Rp6.406,64 lebih rendah dari yang menempati rumah bukan milik sendiri. Sementara itu di perdesaan, rumah tangga miskin yang menempati rumah milik sendiri memiliki pengeluaran listrik Rp1.481,69 lebih rendah dari yang menempati rumah bukan milik sendiri. Pengeluaran yang lebih rendah tersebut kemungkinan karena rumah tangga yang menempati rumah milik sendiri cenderung menggunakan barang yang lebih hemat energi sehingga konsumsinya lebih hemat (Huang, 2015).

Rumah tangga miskin cenderung tidak memiliki barang elektronik yang banyak, sehingga penambahan barang elektronik akan meningkatkan konsumsi listriknya. Penambahan 1 jenis barang elektronik oleh rumah tangga miskin di perkotaan, akan menambah pengeluaran listrik sebesar Rp12.292,01. Sementara di perdesaan, penambahan 1 jenis barang elektronik oleh rumah tangga miskin akan menambah pengeluaran listrik sebesar Rp7.078,77. Dalam menentukan pembelian barang elektronik yang cenderung mahal, rumah tangga akan menimbang harga, kualitas, dan konsumsi energi secara berurutan (Tewathia, 2014). Sehingga jika rumah tangga memiliki barang elektronik yang bervariasi, maka dapat mengindikasikan bahwa rumah tangg a tersebut memiliki ekonomi yang lebih baik karena pengeluaran listriknya lebih tinggi.

\section{KESIMPULAN}

Berdasarkan hasil analisis dan pembahasan penelitian, maka dapat ditarik kesimpulan bahwa rumah tangga miskin di Kawasan Timur Indonesia tahun 2020 lebih banyak berada di perdesaan. Sedangkan pengeluaran listrik rumah tangga miskin di perkotaan lebih tinggi dibanding perdesaan. Untuk karakteristik sosial, umur KRT miskin di perkotaan lebih muda, sebagian besar KRT miskin berpendidikan maksimal SD dan proporsinya lebih kecil di perkotaan, rumah tangga miskin di perkotaan menempati tempat tinggal lebih kecil dibanding perdesaan, dan jumlah ART miskin di kedua daerah sama yaitu antara 5 hingga 6 orang. Untuk karakteristik ekonomi, pendapatan rumah tangga miskin di perkotaan lebih besar, sebagian besar KRT miskin bekerja dan proporsinya jauh lebih banyak di perkotaan, sebagain besar rumah tangga miskin menempati rumah milik sendiri namun proporsinya lebih kecil di perkotaan, dan sebagaian besar rumah tangga miskin di kedua daerah tidak memiliki barang elektronik.

Hasil estimasi dengan metode robust menunjukkan variabel sosial ekonomi yang mempengaruhi pengeluaran listrik rumah tangga miskin di perdesaan dan perkotaan sedikit berbeda. Variabel yang signifikan positif mempengaruhi pengeluaran listrik rumah tangga miskin di perkotaan dan perdesaan KTI tahun 2020 adalah pendidikan tinggi KRT, jumlah ART, luas lantai, pendapatan per kapita, kepemilikan elektronik, dan variabel yang signifikan negatif adalah kepemilikan tempat tinggal. Variabel pendidikan menengah KRT hanya signifikan di perdesaan, sedangkan yang tidak signifikan di perkotaan dan perdesaan KTI tahun 2020 adalah umur KRT dan status bekerja KRT.

\section{DAFTAR PUSTAKA}

Alter, N., \& Syed, S. H. (2011). An Empirical Analysis of Electricity Demand in Pakistan. International Journal Energy Economics and Policy, 1(4), 116.

Andersen, R. (2008). Modern Methods for Robust Regression. Sage.

Bedir, M., Hasselaar, E., \& Itard, L. (2013). Determinants of electricity consumption in Dutch dwellings. Energy and buildings, 58, 194-20. 
Direktorat Gatrik. (2020). Statistik Ketenagalistrikan Tahun 2019. Retrieved Desember 2020, from Direktorat Jenderal Ketenagalistrikan:

https://gatrik.esdm.go.id/assets/uploads/download_index/files/c5eff-statistik-ketenagalistrikan-2019final-.pdf

Draper, N., \& Smith. (1998). Applied Regression Analysis, Third Edition. United States: Wiley.

Huang, W. H. (2015). The determinants of household electricity consumption in Taiwan: Evidence from quantile regression. Elsevier Energy 87, 120 - 133.

Kammen, D., \& Kirubi, C. (2008). Poverty, Energy, and Resource Use in Developing Countries. Annals of the New York Academy of Sciences, 1136(1), 348-357.

Kementrian ESDM. (2017). Kebijakan Subsidi Listrik Tepat Sasaran Rumah Tangga Daya 900VA. Retrieved Desember 2020, from Kementrian Energi dan Sumber Daya Mineral: https://www.esdm.go.id/assets/media/content/content-kebijakan-subsidi-listrik-tepat-sasaran-rumahtangga-daya-900-va.pdf

Kim, M. J. (2020). Understanding the determinants on household electricity consumption in Korea: OLS regression and quantile regression. The Electricity Journal 33, 106802.

Nazer, M., \& Handra, H. (2016). Analisis Konsumsi Energi Rumah Tangga Perkotaan di Indonesia: Periode Tahun 2008 dan 2011. Jurnal Ekonomi dan Pembangunan Indonesia Vol. 16, 141-153.

Nurdin, N., Raupong, \& Islamiyati, A. (2014). Penggunaan Regresi Robust Pada Data yang Mengandung Pencilan dengan Metode Momen. Jurnal Matematika, Statistika, dan Komputasi, X, 114-123.

Petersen, H. (1982). Electricity Consumption in Rural vs Urban Areas. Western Journal of Agricultural Economics, ol. 7, No. 1, 13-18.

Purnomo, S. D. (2020). Faktor-Faktor yang Mempengaruhi Pengeluaran Listrik Rumah Tangga. Indonesian Journal of Development Economics Efficient Vol 3 (1), 710 -718.

Romadhoni, B., \& Akhmad. (2020). Household Electricity Demand in South Sulawesi, Indonesia. International Journal of Energy Economics and Policy, 10(4), 229 - 233.

Stuart, C. (2011). Robust Regression. Department of Mathematical Sciences, Durham University, 169.

Sukirno, S. (2013). Mikroekonomi: Teori Pengantar. Edisi Ketiga. Jakarta: PT Raja Grafindo Persada.

Susanti, Y., Pratiwi, H., \& Sulistijow, S. (2013). Optimasi Model Regresi untuk Memprediksi Produksi Kedelai di Indonesia. Seminar Nasional Matematika dan Pendidikan Matematika (pp. 253-262). Yogyakarta: Jurusan Pendidikan Matematika FMIPA UNY.

Tewathia, N. (2014). Determinants of the Household Electricity Consumption: A Case Study of Delhi. International Journal of Energy Economics and Policy Vol. 4, No. 3, 337-348.

Wijaya, M. E., \& Tezuka, T. (2013). A comparative study of households' electricity consumption characteristics in Indonesia: A techno-socioeconomic analysis. Energy for Sustainable Development, 596 $-604$.

Wilcox, R. (2011). Introduction to Robust Estimation and Hypothesis Testing (3rd Edition). Academic Press.

Wilder, P., \& Willenborg, J. (1975). Residential Demand for Electricity: A Consumer Panel Approach. Southern Economic Journal 42(2), 212-217.

Yohai, V. (1987). High Breakdown Point and High Efficiency Robust Estimates for Regression. The Annals of Statistics, Vol. 15, No. 20, 642-656.

Yohanis, Y., Mondol, J., Wright, A., \& Norton, B. (2008). Real-life energy use in the UK: How occupancy and dwelling characteristics affect domestic electricity use. Energy and Buildings 40, 1053-1059.

Zuhri, K. (2019). Ketimpangan Akses Energi Listrik dan Kemiskinan di Indonesia. Tesis Institut Pertanian Bogor. Bogor. $91 \mathrm{hlm}$.

Zuhri, K., Anggraeni, L., \& Irawan, T. (2018). Inequality in Indonesia's Electricity Access. International Journal of Sciences: Basic and Applied Research (IJSBAR). 